\title{
The Electrophysiological Manifestation of Dutch Verb Second Violations
}

\author{
Dirk-Bart den Ouden · Roelien Bastiaanse
}

Published online: 29 March 2009

(C) The Author(s) 2009. This article is published with open access at Springerlink.com

\begin{abstract}
We investigated the processing of violations of the verb position in Dutch, in a group of healthy subjects, by measuring event-related potentials (ERPs) through electroencephalography (EEG). In Dutch, the base position of the verb is clause final, but in matrix clauses, the finite verb is in second position, a construction known as Verb Second. In embedded clauses, the finite verb remains in its clause-final base position. The results show that ungrammatical placement of finite verbs in second position in embedded clauses yields a P600 response, which suggests that the parser treats this type of violation as a clear syntactic anomaly. This is in contrast to accounts by which a general preference for subject-verb-object word order in languages like Dutch is reflected by an absence of P600 effects in response to violations of Verb Second.
\end{abstract}

Keywords Verb Second $\cdot$ Verbs $\cdot$ ERP $\cdot$ P600 $\cdot$ Dutch $\cdot$ Syntax

\section{Introduction}

Results from off-line production studies indicate that the problems that Dutch agrammatic aphasic speakers as well as children with specific language impairments have with verb production are, at least partially, syntactic in nature (Bastiaanse et al. 2002). In this respect, the Verb Second (V2) construction, by which finite verbs are placed in second sentence position in Dutch matrix clauses (Den Besten 1977), is argued to be a particular instance of a construction that causes syntactic processing difficulties in impaired speakers. The current study investigates whether violation of the V2 construction is associated with Event-Related

D.-B. den Ouden $(\varangle)$

Aphasia and Neurolinguistics Research Laboratory, Department of Communication Sciences and Disorders, Northwestern University, 2240 Campus Drive, Evanston, IL 60208-3066, USA e-mail: d-ouden@northwestern.edu

D.-B. den Ouden · R. Bastiaanse

School of Behavioural and Cognitive Neurosciences (BCN), University of Groningen,

Groningen, The Netherlands 
Potential (ERP) effects marked as syntactic components, which would indicate that such violations are processed as syntactic anomalies by unimpaired speakers (Friederici 1995; Kaan et al. 2000).

Although the precise nature of the V2 construction in continental West Germanic languages is a topic of debate in the field of formal syntax, both structurally and derivationally, it is generally analyzed as a derivation from the embedded clause construction, in which finite verbs are found in final position (cf. Zwart 2001, 2003). Example 1a shows the subject finite-verb object $\left(\mathrm{SV}_{\mathrm{f}} \mathrm{O}\right)$, or $\mathrm{V} 2$ order found in main clauses, while $1 \mathrm{~b}$ shows the $\mathrm{SOV}_{\mathrm{f}}$ order of Dutch embedded clauses.

\section{(1a) Lucy knuffelt Victor Lucy hugs Victor}

(1b) Ik weet dat Lucy Victor knuffelt

I know that Lucy hugs Victor

Notably, structural frequency data show that V2 is almost twice as frequent as the verb-final construction (cf. Den Ouden et al. 2008; Bastiaanse et al. 2009), which creates an interesting dissociation with the formal syntactic analysis of a structure requiring an 'extra step', as well as with the relative difficulty that agrammatic speakers have with V2. Using fMRI, Den Ouden et al. (2008) have shown that production of V2 constructions in Dutch is indeed associated with increased neural processing in healthy speakers, as compared to production of phrases in which the verb is in its sentence-final, or base, position.

ERPs provide a fairly direct window on the time course of cognitive processing. Specific components, characterized by their latency, amplitude and topographical distribution, have been related to different processing stages. Of interest in the present study is the P600 effect (Osterhout and Holcomb 1992), which is taken to reflect cognitive effort in sentence reanalysis. This component is found in cases of syntactic ungrammaticality, but also in response to relative syntactic complexity, or in garden-path sentences in which the ungrammaticality is only temporarily apparent and can be resolved with reanalysis (Kaan et al. 2000). Before the P600, syntactic violations of word order often show a left anterior negativity (LAN; 300$500 \mathrm{~ms}$ ), associated with structure-building failure, as caused by morphosyntactic violations, as well as by phrase structure violations (Neville et al. 1991; Coulson et al. 1998; Hagoort 2005; Ullman 2004). An early LAN (ELAN; 100-150 ms), is a specific response to phrase structure violations caused by word category errors (Friederici et al. 1993), but it is not always observed, perhaps only in severe and immediately clear violations. LAN components have been described as reflecting the first pass in syntactic processing, equivalent to an alarm going off in case of syntactic anomaly, whereas the P600 reflects a second pass effort in structure building or anomaly resolution, that is, the response to the alarm (see Friederici 2002).

The timing of these components is principally derived from studies in which language stimuli were presented visually, either word-for-word or phrase-by-phrase. As we plan to investigate ERP effects to syntactic violations in subjects with (agrammatic) aphasia, and compare these to our results in healthy participants, we chose to present our stimuli in auditory mode. Many people with aphasia after stroke have reading problems, certainly with the speed at which word stimuli are generally presented in ERP experiments. Slowing down the speed of presentation would make the experiment and the parsing process even less reflective of normal language processing outside laboratory conditions. Rather, we chose the auditory presentation mode, at a moderate, but still 'natural' rate of speech. In general, auditory presentation is found to yield ERP results that are comparable to visual presentation (e.g., Osterhout and Holcomb 1993), while it is a more natural stimulation mode than visual presentation, for experiments on language structure and processing. Nevertheless, the timing 
of the critical time point in auditorily presented input is less straightforward than in visual presentation, where it is usually the moment at which the critical word appears on the screen. We therefore chose to perform two analyses, with event time points set at both the onset and the offset of our critical stimuli.

The ERP responses to auditory processing of V2 in healthy speakers are of interest independently as well, particularly as a study by Weyerts et al. (2002) suggests that in another V2 language, German, processing of verbs in second clause position (immediately following the grammatical subject) is preferred over the processing of verbs in sentence-final position. This processing preference is reflected by an increased negativity associated with sentence-final finite verb placement, and even holds in cases where the V2 placement is ungrammatical, as in embedded clauses (Weyerts et al. 2002). In terms of verb placement and the V2 construction, German and Dutch are highly similar, so these are results that bear on our work on Dutch syntactic processing. While we agree that there may well be a pragmatic preference for V2 constructions, if only based on structural frequency, the absence of the syntactic P600 response to violations of V2 is against our predictions for Dutch, based on linguistic theory and aphasiological and neurolinguistic data.

In light of the account that impaired syntactic processing is at the core of sentence production and comprehension problems in agrammatic aphasia, rather than semantic or more general pragmatic factors, it is important to investigate whether a syntactic construction that appears to cause particular difficulty in Dutch, viz., V2, is indeed associated with syntactic preferences. Specifically, if ungrammatical placement of finite verbs in second clause position does not yield an ERP component that marks it as a syntactic violation, it becomes more tenable that V2 is simply always preferred over verb-final constructions in Dutch, and more difficult to maintain a syntactically-based account for the relative problems that aphasic speakers and children with SLI have with the production of V2 constructions. We have therefore tested directly the ERP effects in response to the processing of ungrammatical V2 constructions in Dutch.

Based on our earlier research, we hypothesize that violations of V2, in the form of finite verbs placed in second clause position where this is not warranted by the syntax, will yield a clearly identifiable and significant P600 ERP response in healthy speakers of Dutch. We do not make a strong prediction with regard to (E)LAN effects, because it is possible that the V2 violations we present are not immediately recognized as ungrammatical, for example because this requires the parser to recognize not only the presence of a finite verb, but also its type (transitive as opposed to intransitive). In addition, the grammatical $\mathrm{SV}_{\mathrm{f}}(\mathrm{O})$ construction is highly frequent in Dutch, in matrix clauses, which may help to dampen its recognition as ungrammatical in embedded clauses.

\section{Methods}

\section{Subjects}

Eleven healthy, right-handed native speakers of Dutch participated in the study, after giving informed consent. Due to technical error, one subject's data were not suitable for analysis and therefore excluded. The remaining 10 participants ( 5 females) had a mean age of 57.2 years (40-75). We recruited in this age range for anticipatory purposes of age matching, as we plan to follow-up on the present experiment with measurements of Dutch agrammatic speakers' electrophysiological responses to the same stimuli. All participants gave their informed consent, and were paid for their time. 
Materials

Of the complete list of 180 stimuli, $50 \%$ were grammatically correct. The two experimental conditions consisted of 40 grammatical verb-second constructions (2a), and 40 ungrammatical verb-second constructions ( $2 \mathrm{~b}$ ), with only monosyllabic verbs at the critical positions (see Appendix). In the stimuli, we made use of the fact that Dutch coordinating clauses take the V2 construction, while in embedded clauses, verbs should be in final position, following the object. In sentence $2 b$, the critical clause is embedded and, therefore, the finite verb ('rents') should be at the end ('... the student an apartment rents).

(2a) De klas giechelt, want de meester wekt het meisje the class giggles, because (coord.) the teacher wakes the girl ${ }^{1}$

(2b) *De ouders treuren, omdat de student huurt een kamer

the parents mourn, because (embed.) the student rents an apartment

Experimental sentence stimuli were matched for the number of words. Critical verbs (underlined in 2) were monosyllabic and matched for lemma frequency based on the CELEX database (Baayen et al. 1995). All critical verbs were of relatively high lemma frequency ( $\log$ frequency $>1.2$ ). All critical verbs were obligatorily transitive, with an agent as the thematic role of the grammatical subject.

In 40 related fillers, 20 of which were grammatical (3a) and 20 ungrammatical (3b), the verb was placed sentence-finally.

(3a) Het proefwerk begint, terwijl de spijbelaar een hut bouwt

the exam starts, while (embed..) the truant a hut builds

(3b) *De docent zucht, want de puber de school haat

the teacher sighs, because (coord.) the teenager the school hates

These related fillers were included to avoid predictability in the experimental items, but they were not suited for analysis of the electrophysiological response to grammaticality violations on verb position, as the violation in fact takes place on the verb's preceding NP (cf. 2b). We wanted to avoid comparing ERP effects on nouns with those on verbs, and we also wanted to avoid analysis of sentence-final ERPs, as they tend to be influenced by sentence wrap-up effects (Hagoort et al. 2003; Osterhout et al. 1994). Therefore, we chose to test our hypothesis by comparing grammatical and ungrammatical verb placement only in mid-sentence.

In addition, 30 unrelated grammatical fillers and 30 unrelated ungrammatical fillers were included, of various constructions (4).

(4a) Hij heeft veel voor zijn studieboeken uitgegeven

he has spent a lot on his textbooks

Filler Type: not a compound sentence; grammatical

(4b) *Tijdens het examen overlegt alle kinderen

during the exam all children discusses

Filler Type: subject-verb number agreement error

Stimuli were digitally recorded by a female speaker, at a $44 \mathrm{kHz}$ sample rate, and normalized to $70 \mathrm{~dB}$. The mean sentence duration for the complete set of stimuli was $2956 \mathrm{~ms}$ (SD 677),

\footnotetext{
${ }^{1}$ In the literal translation of our examples, in the text as well as in the Appendix, we have chosen to use the English simple present tense, although in most of these cases, the progressive tense would be applied in normal English usage. This is to reflect the finite tense marking in Dutch, which does not usually apply the progressive tense in these sentences.
} 
while the mean sentence duration for the two experimental conditions was $3371 \mathrm{~ms}$ (SD 320). For precise placement of the correct time markers in our data, we calculated the time from sentence onset to critical-verb offset, which was our main time point of interest, as well as the duration of these critical verbs (mean $289 \mathrm{~ms}$, SD 56).

\section{Procedure}

Stimuli were presented with EPrime software (version 1.1; Schneider et al. 2002). Seated in front of a computer screen, participants performed a delayed grammaticality judgment task on auditorily presented sentences, while their EEGs were being collected. A total of $1000 \mathrm{~ms}$ before sentence-onset, a fixation cross appeared in the center of the computer screen. Subjects were instructed not to move or blink during the presentation of this fixation cross, which remained on screen until $1000 \mathrm{~ms}$ after the offset of each sentence. At this point, subjects were allowed to blink and move their eyes, continuing into the grammaticality judgment task. After $1500 \mathrm{~ms}$, subjects were cued to give their grammaticality judgment, through the appearance of the word "Correct?" on the screen. Subjects gave a yes/no button-press response. The following trial started $500 \mathrm{~ms}$ after the response or, if no response is given, after $3000 \mathrm{~ms}$. Single trials had a maximum duration of $10 \mathrm{~s}$ in total, with variable sentence durations. The total duration of the experiment was about $30 \mathrm{~min}$, divided into three 10 -min blocks.

\section{EEG Recording}

The electroencephalogram (EEG) was recorded with Brain Vision Recorder software (Brain Products) using 64 tin electrodes attached to an electrocap, according to the 10-20 system, with the nomenclature as proposed by the American Electroencephalographic Society (1994). Electrodes were connected to an average-reference high input-impedance amplifier ( $>10^{12} \Omega$; Twente Medical Systems, Enschede, the Netherlands). All electrodes were referenced to linked earlobes. The recording of the electro-oculogram (EOG) was bipolar, from the outer canthi of both eyes and above and below the left eye. Electrode impedance was kept below $20 \mathrm{k} \Omega$, to avoid skin abrasion (Ferree et al. 2001). EEG and EOG were recorded at a sample rate of $2000 \mathrm{~Hz}$, with a $560 \mathrm{~Hz}$ low pass filter.

\section{ERP Analysis}

All ERP analyses were performed using Brain Vision Analyser software (Brain Products). The data were downsampled to $250 \mathrm{~Hz}$ and filtered with a $0.1 \mathrm{~Hz}$ high-pass filter and a slope of $24 \mathrm{~dB} /$ oct and a $35 \mathrm{~Hz}$ low-pass filter with a slope of $24 \mathrm{~dB} /$ oct. Before segmentation, bad channels were marked for exclusion of further analysis. Data were segmented, after which eye movement artifacts were corrected using the Gratton et al. (1983) method, and any trials with remaining artifacts were removed, based on visual inspection of the data, as well as on a gradient criterion of maximally $50 \mu \mathrm{V}$ per sample point, a difference criterion of maximally $200 \mu \mathrm{V}$ per segment, and an amplitude criterion of $-200 \mu \mathrm{V}$ and $200 \mu \mathrm{V}$. This led to rejection of $5.9 \%$ of the total number of trials.

Trials with incorrect or no responses were excluded from statistical analysis, so that of our experimental stimuli, a total of $8.3 \%$ of trials was excluded from the correct verb-placement condition (1a), and a total of $8.7 \%$ of trials was excluded from the incorrect verb-placement condition (1b).

We chose to investigate the ERPs relative to two time points. The primary time point we investigated was the offset of the critical verbs in our experimental sentences. The reason 
for choosing the verb offset as our critical time point is that in auditory presentation, these verbs are presented incrementally to the listener, so that there is no cue at the beginning of the verb as to what (type of) word will unfold. While it is true that there is a critical point of word identification that lies before the end of the word (cf. Van den Brink 2004), we chose to circumvent the computation of this point for each individual verb stimulus by placing time 0 directly at the verb offset. However, as a check, we also performed a separate segmentation, in which we placed our time markers $289 \mathrm{~ms}$ back (i.e., the mean verb duration), in order to capture the ERPs relative to verb onsets. We report the results of both the analyses that follow from these different segmentations, with an emphasis on the verb offset results, as this was our main target. All single-subject averages for the different conditions were computed over segments of $2000 \mathrm{~ms}$ post-event, relative to $200 \mathrm{~ms}$ of pre-event baseline activation.

Because of the auditory presentation of stimuli, latencies of expected components might differ from those associated with visual presentation. Previous work with auditory presentation (Friederici et al. 1999; Rispens 2004), suggested that we might expect the relevant two time windows to be around $200-400 \mathrm{~ms}$ for the LAN and around 700-1200 ms for P600 effects. For each subject, mean amplitude values were computed in these latency windows. Other time windows would be chosen based on visual inspection of the data.

For statistical analysis, electrodes were pooled into the following regions of interest: leftanterior (L-ANT: F3, F7, FC5); right-anterior (R-ANT: F4, F8, FC6); left-posterior (L-POST: CP5, P3, P7); and right-posterior (R-POST: CP6, P4, P8). ERP effects were statistically computed in repeated-measures ANOVAs for each time window of interest, with verb placement as a two-level within subjects factor (correct and incorrect), and electrode position as a seven-level within subjects factor, viz., L-ANT, R-ANT, L-POST, R-POST, and three midline electrodes, Fz, Cz, and Pz. In case of inhomogeneities of variance, reported p-values were Greenhouse-Geisser corrected.

\section{Results}

Figure 1 shows the grand average ERP effects of V2 violations measured from the verb offset, whereas Fig. 2 is an additional illustration of the scalp distribution of the difference between the conditions over time, based on our 62 scalp electrodes. Visual inspection of the data shows a positivity associated with violations of V2 placement, starting at around $300 \mathrm{~ms}$ and lasting until about $1100 \mathrm{~ms}$, with a midline and bilaterally posterior distribution, which fits the general definition of a P600 effect. There is no sign of an (E)LAN effect to the V2 violation.

This picture is confirmed by the ANOVAs of the mean amplitudes. In the 200-400 time latency window, there is no main effect of verb placement, but there is an effect of electrode position $(F(6,54)=6.29, p<.001)$, mostly due to midline electrodes showing greater positivity than the other regions $(p<.05)$. The interaction between verb placement and electrode position only approaches significance $(F(6,54)=3.18, p=.062)$, but does reflect the early start of the positive shift in response to V2 violations, being due not to so much to increased negativity for violations (although L-ANT $(-0.091 \mu \mathrm{V})$ and R-ANT $(-0.262 \mu \mathrm{V})$ do show this), but rather to increased positivity over posterior electrodes (L-POST $449 \mu \mathrm{V}$; R-POST $394 \mu \mathrm{V}$; Fz $647 \mu \mathrm{V}$; Cz $1.215 \mu \mathrm{V}$; and Pz $1330 \mu \mathrm{V}$ ). In order to confirm that there was also no anterior negativity before our chosen time window, we performed an additional ANOVA over the time latency window of $100-250 \mathrm{~ms}$. This yielded no main effects, nor interactions. 


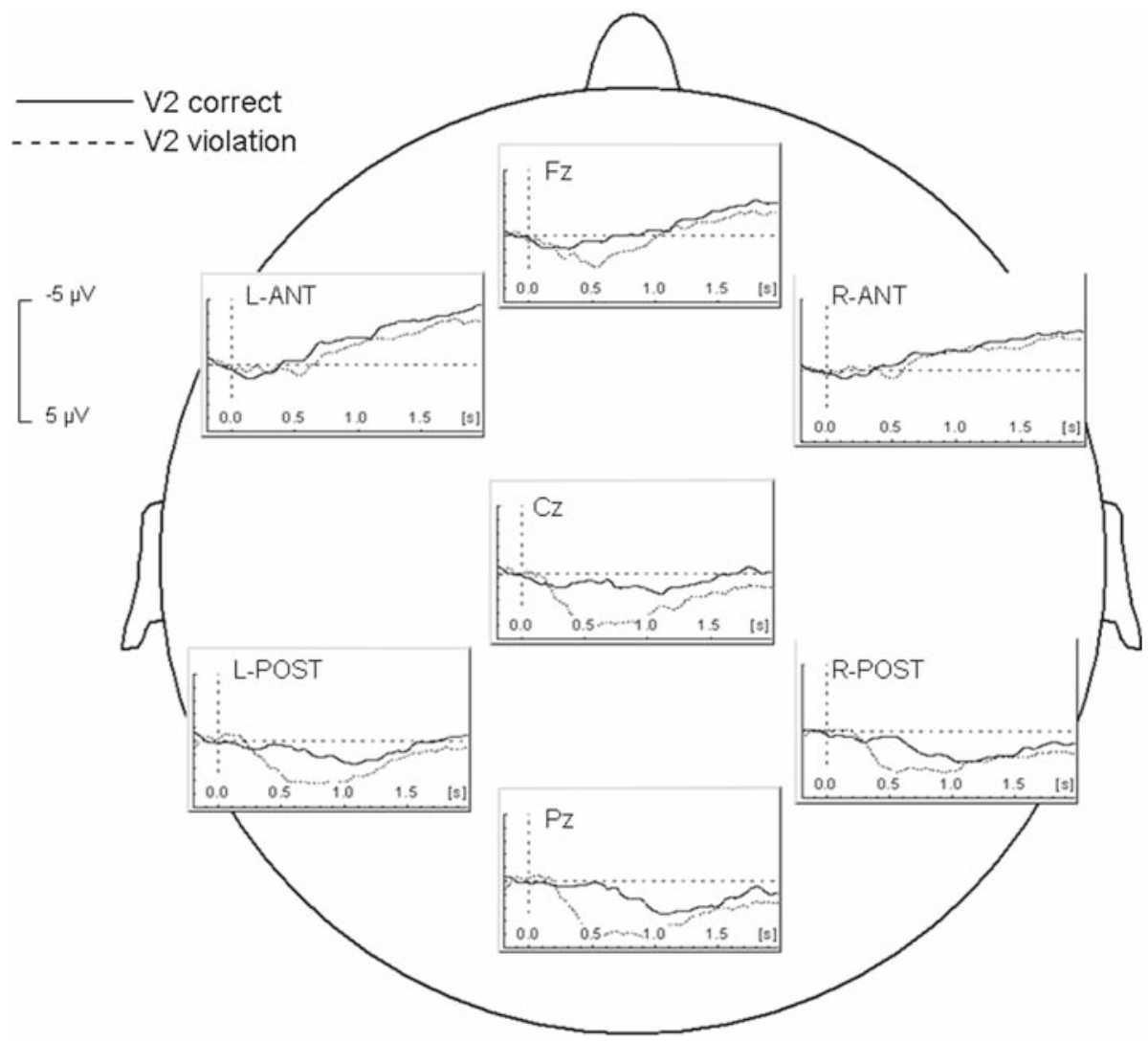

Fig. 1 Grand average ERPs showing the effects of verb second violations as measured from the verb offset. Negative voltage is plotted up. Relative to correct verb placement, violations of verb second yield a positivity, starting at around $300 \mathrm{~ms}$ and lasting up to around $1100 \mathrm{~ms}$, primarily distributed over midline and bilateral posterior electrodes

In the 700-1200 ms latency window, there is a main effect of verb placement $(F(1,9)=6.21$, $p=.034)$, reflecting greater positivity for verb-second violations $(1.5 \mu \mathrm{V} v \mathrm{vs} .0 .4 \mu \mathrm{V})$ as well as a main effect of electrode position $(F(6,54)=20.76, p<.001)$, with L-ANT and R-ANT sites being significantly more negative than the other regions $(p<.01)$ and the Fz electrode showing significantly greater positivity than L-ANT and R-ANT and significantly greater negativity than L-POST, R-POST, $\mathrm{Cz}$ and $\mathrm{Pz}(p<.01)$. There is also a significant interaction between verb placement and electrode position $(F(6,54)=4.95, p<.001)$, with the positive shift associated with incorrect verb placement being greatest posteriorly, as visible in Fig. 1. Both the time latency and the bilaterally posterior distribution of the positive shift in response to V2 violations mark it as a P600 effect.

To further investigate our ERP data relative to a more conventional time point, at least for visual presentation of language stimuli, we performed an alternative analysis of our data with time 0 set to the mean onset of our critical verb stimuli. Illustrations of the results are given in Figs. 3 and 4.

The results are very much the same as for our previous analysis, be it that the components are found later when time 0 is placed at the mean verb onset. In the $200-400 \mathrm{~ms}$ latency 


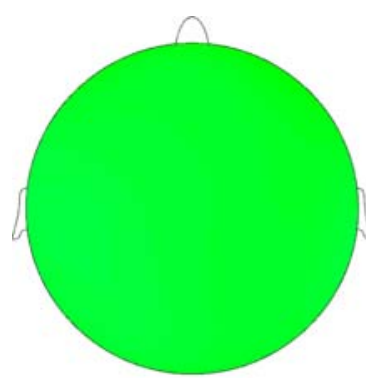

$0.000-0.164 \mathrm{~s}$

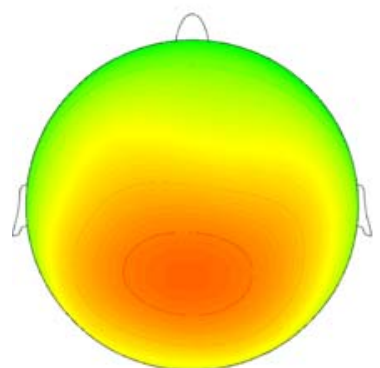

$0.500-0.664 s$

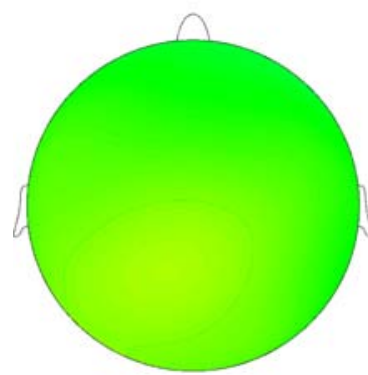

$1.000-1.164 \mathrm{~s}$

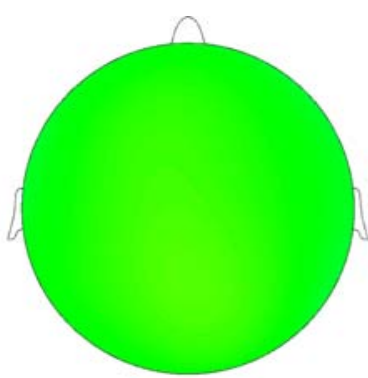

$0.168-0.332 \mathrm{~s}$

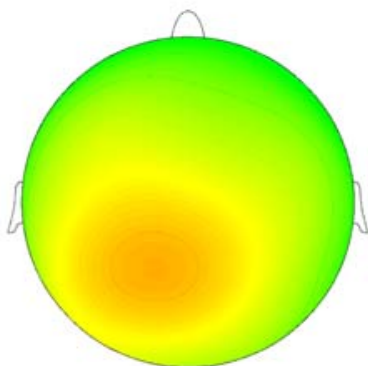

$0.668-0.832 s$

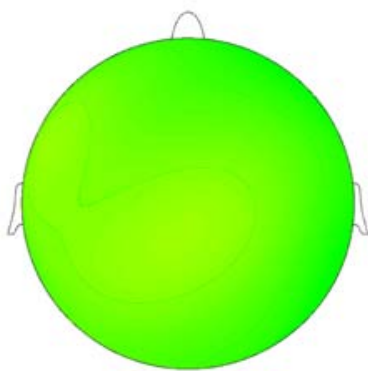

$1.168-1.332 \mathrm{~s}$

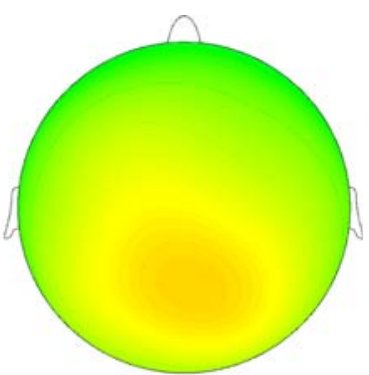

$0.332-0.496 s$

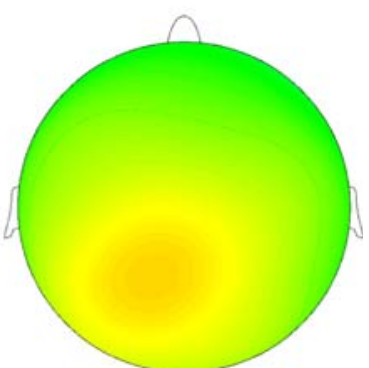

$0.832-0.996 \mathrm{~s}$

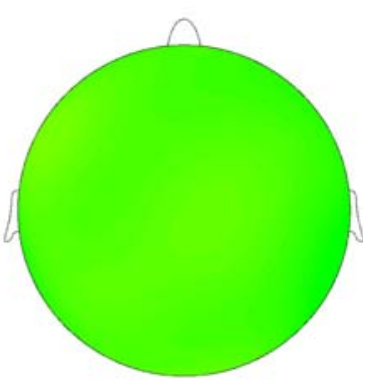

$1.332-1.496 \mathrm{~s}$

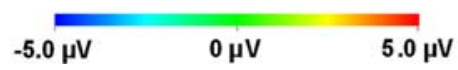

Fig. 2 Scalp distribution of ERP effects of verb second violation, relative to correct verb placement, between 0 and $1500 \mathrm{~ms}$ after critical verb offset, based on 62 electrode sites

window, there is no main effect of verb placement, and no interaction, but only a main effect of electrode position $(F(6,54)=4.35, p=.001)$, mainly driven by a relatively great positivity in the L-ANT region, compared to R-ANT, R-POST and Pz $(p<.05)$. L-POST is also more positive than R-POST $(p<.05)$, while Fz and $\mathrm{Cz}$ are both more positive than $\mathrm{Pz}(p<.05)$.

The 700-1200 ms latency window shows a main effect of verb placement $(F(1,9)=8.56$, $p=.017)$, due to a greater overall positivity after violation of $\mathrm{V} 2(0.168 \mu \mathrm{V}$ vs. $1.93 \mu \mathrm{V})$. There is also a main effect of electrode position $(F(6,54)=11.38, p=.001)$, due to the L-ANT and R-ANT regions being more negative than the other regions and electrodes $(p<.05)$, while the Fz electrode is (marginally) more negative than L-POST, R-POST, Cz and Fz. More importantly, there is a significant interaction between verb placement and electrode position 


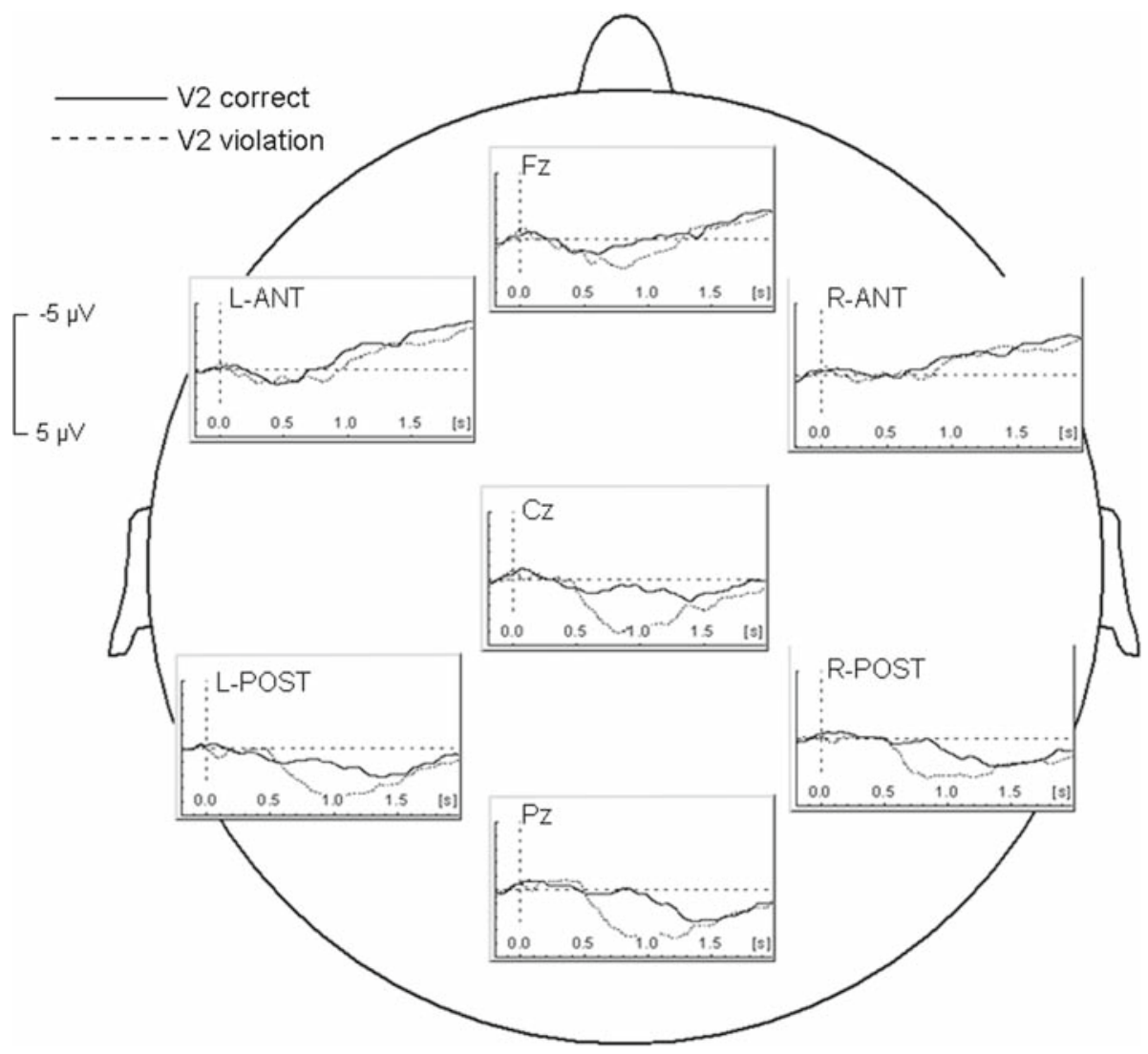

Fig. 3 Grand average ERPs showing the effects of verb second violations as measured from the verb onset. Negative voltage is plotted up. Relative to correct verb placement, violations of verb second yield a positivity, starting at around $500 \mathrm{~ms}$ and lasting up to around $1400 \mathrm{~ms}$, primarily distributed over midline and bilateral posterior electrodes

$(F(6,54)=5.78, p=.011)$, with the positive shift being greater over midline and bilateral posterior electrodes. Again, the time latency and distribution indicate that the ERP response to violation of $\mathrm{V} 2$ is a P600 effect.

In sum, violations of V2 in Dutch are met with a P600 ERP response. This is visible in an analysis where the critical time point is the verb offset, that is, when the whole verb has been presented, as well as in an analysis in which the critical time point is the mean verb onset. In neither analysis is there an indication of (E)LAN effects in response to V2 violation.

\section{Discussion}

Whether the time-lock for analysis is placed at the offset or the onset of auditorily presented critical verbs, ungrammatical placement of verbs in V2 position yields a clear P600 ERP response in Dutch listeners. This means that such violations are treated as the syntactic anomalies that they are, and that the parser makes a specific effort to reanalyze these sentences in response to their ungrammaticality. 


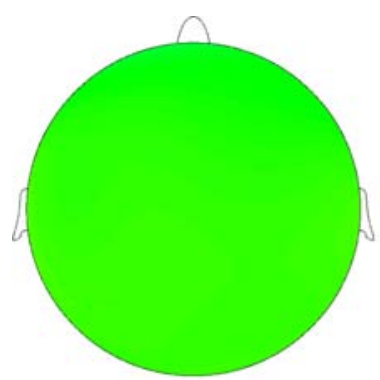

$0.000-0.164 \mathrm{~s}$

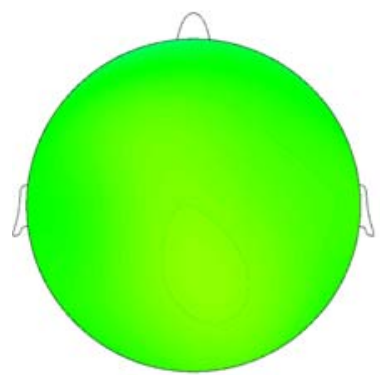

$0.500-0.664 \mathrm{~s}$

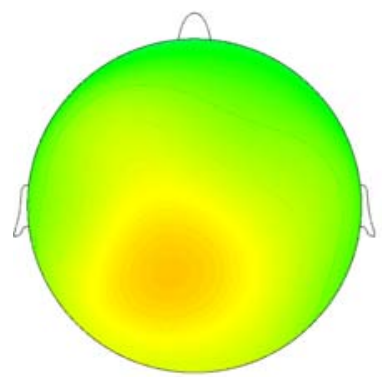

$1.000-1.164 \mathrm{~s}$

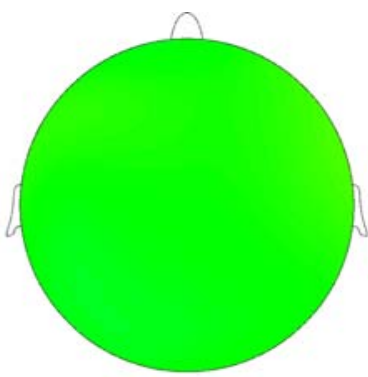

$0.168-0.332 \mathrm{~s}$

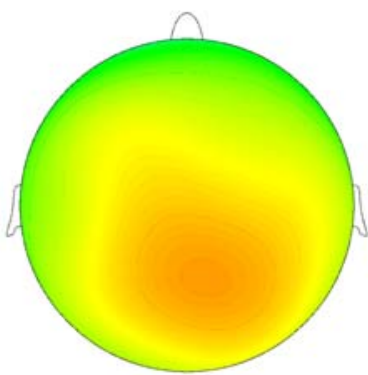

$0.668-0.832 \mathrm{~s}$

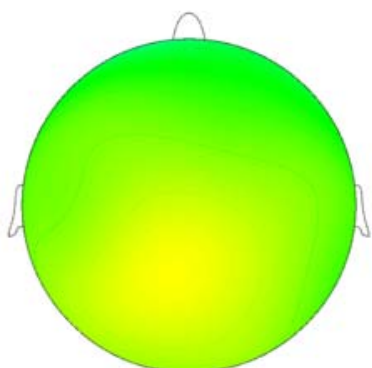

$1.168-1.332 \mathrm{~s}$

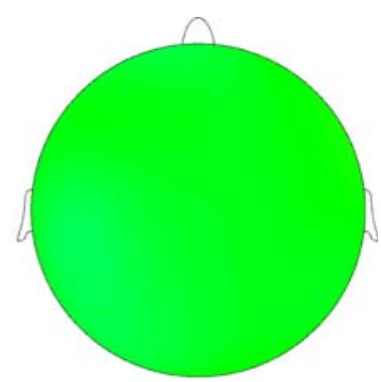

$0.332-0.496 \mathrm{~s}$

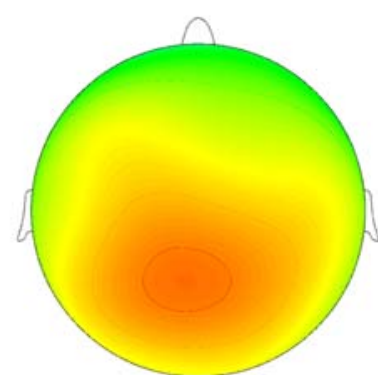

$0.832-0.996 \mathrm{~s}$

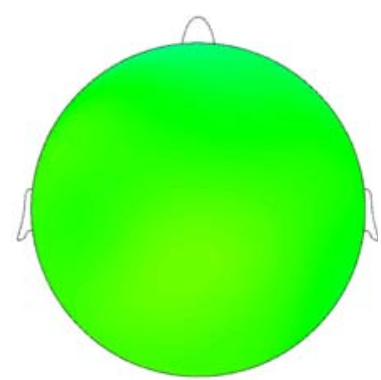

$1.332-1.496 \mathrm{~s}$

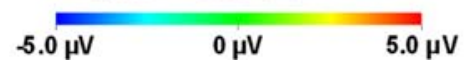

Fig. 4 Scalp distribution of ERP effects of verb second violation, relative to correct verb placement, between 0 and $1500 \mathrm{~ms}$ after critical verb onset, based on 62 electrode sites

The absence of (E)LAN effects indicates that the syntactic ungrammaticality alarm does not go off immediately after verb presentation. We argue that this may be due to the nature of the syntactic violation, which takes more steps to detect than, e.g. violations of subject-verb agreement, or word-order violations that are never possible in any syntactic context. Note that it is not necessarily ungrammatical to have a finite verb follow a subject NP in Dutch. In the present experiment, the parser needs to establish not only that a finite verb has followed a subject in an embedded clause, but additionally that this verb is obligatorily transitive, which requires it to be preceded by an object NP in embedded clauses. It is only the combination of those two facts that makes the construction ungrammatical. As such, the absence of (E)LAN 
effects may be explained by the fact that there is no immediate cause for alarm in these sentences.

With behavioral experiments, Shapiro and colleagues (cf. Shapiro et al. 1991; see Shapiro 2003) have shown that complexity of verbs in terms of their argument structure affects processing very rapidly after verb presentation, indicating that access to argument structure as part of the lexical representation of verbs is automatic and fast. For that reason, one might have expected an (E)LAN effect where a transitive verb follows the absence of an obligatory argument. However, in contrast to these behavioral experiments, which often use CrossModal Lexical Decision on words presented at certain time points in grammatically correct sentences, the current experiment investigates grammatical violations. As sketched above, this may complicate the processes at work, as lexico-semantic expectations (verb argument structure) and syntactic expectations (word order by phrase type) may affect one another.

ERP experiments by Friederici and Frisch (2000) show that the presence of pre-verbal arguments (in German SOV constructions) influences lexical retrieval, in that it narrows down the expected transitivity of the upcoming verb. Interestingly, though, in cases where an internal object NP is (ungrammatically) followed by an intransitive verb, this leads to an N400 effect, reflecting lexical integration problems (Kutas and Hillyard 1984), i.e., violation of a lexico-semantic expectation. No (E)LAN is observed in such conditions, but there is a $\mathrm{P} 600$, suggesting that the parser treats the argument-number violation at first only as a semantic problem, and only subsequently as a syntactic integration problem. Our current study is again altogether different, in that one might say the verb is only preceded by the absence of arguments, so there may not be a 'build-up' of argument structure expectations yet, when we present our critical transitive verb in the condition that violates the subordinate-phrase order of SOV. This may account for the absence of an N400 effect, which might have been expected, based on the data and interpretation offered by Friederici and Frisch (2000). Frisch et al. (2004) also show that verb argument structure violations only elicit an N400 if they do not co-occur with a phrase structure violation. In case these two violations do co-occur, the ERPs show a LAN effect. Their results suggest that the successful integration of a verb's syntactic category is a functional prerequisite for the evaluation of its argument-structure. In our case, it is precisely the transitivity of the verb itself that makes its place in the sentence ungrammatical. The phrase-structure violations used by Frisch et al. (2004) were preposition-determiner-verb compounds (“... on the worked ...”), i.e., always impossible in German, whereas the word order violation used in the present study is critically only a violation in its subordinate-clause context. ${ }^{2}$

Although the present experiment is much less elaborate than that of Weyerts et al. (2002), the question is raised why there is a difference in the results obtained in the two studies, on German and Dutch. Weyerts et al. (2002) show that ungrammatical SV $\mathrm{f}_{\mathrm{f}} \mathrm{O}$ constructions only yield an insignificant trend towards a P600 component. Ungrammatical $\mathrm{SOV}_{\mathrm{f}}$ constructions, on the other hand, result in a clear and statistically significant P600 effect. Our present results show that, in Dutch, ungrammatical $\mathrm{SV}_{\mathrm{f}} \mathrm{O}$ embedded constructions do yield a strong P600 response. We do not have a syntactic explanation for the difference between the two studies, as we do not assume differences in the syntactic construction, nor in the processing preferences, between the two languages. Also, we do not believe the cause of the difference lies in the different presentation modes, visual (Weyerts et al. 2002) versus auditory (present study), if only because they do find clear ERP components, including the P600, in other conditions.

\footnotetext{
2 Note that the P600 effect reported here can only be interpreted as reflecting a violation of the verb's argument structure if the obligatory SOV word order in subordinate clauses is assumed, reinforcing the point we make in this paper.
} 
One possible explanation for the absence of the P600 response to V2 violations in the Weyerts et al. (2002) study, is that their experimental stimuli do contain quite a few verbs that are not obligatorily transitive in their use. For example, sentence $4 \mathrm{a}$ is grammatical up to the final NP Omeletts (omelettes), as the verb wenden (to turn) can be used both transitively and intransitively. So, it is only the final NP that makes this trial ungrammatical, and not the verb as such, while it is the onset of the verb that was used as the critical time point for this stimulus, in the comparison with grammatically correct sentence $4 \mathrm{~b}$.

(4a) *Den Gast beeindruckt sehr, wie die Köchin wendet Omeletts.

(4b) Den Gast beeindruckt sehr, wie die Köchin Omeletts wendet.

The guest is very impressed by the way the cook $_{\text {fem }}$ turns (omelettes).

By our estimation, at least 15 of the 68 verbs (in their critical experiment 2) are of this socalled 'pseudotransitive' type, so it might be interesting to see what the influence of these stimuli is on the complete dataset. In our own stimuli (see Appendix), we have deliberately tried to use only verbs that are as strongly transitive as we found possible.

In addition, we wish to raise another possible methodological issue with the argument made by Weyerts et al. (2002) on the basis of their ERP results, in favor of a preference for $\mathrm{SV}_{\mathrm{f}} \mathrm{O}$ structures in German sentence processing that overrides ungrammaticality. Weyerts et al. (2002) directly compare ERPs to $\mathrm{SOV}_{\mathrm{f}}$ and $\mathrm{SV}_{\mathrm{f}} \mathrm{O}$ sentences, both grammatical and ungrammatical, and claim that the preference for $\mathrm{SV}_{\mathrm{f}} \mathrm{O}$ is reflected by an increased anterior negativity for $\mathrm{SOV}_{\mathrm{f}}$ sentences, interpreted as a syntactic component. However, in their analysis, the critical-event time locks are placed at the onsets of $\mathrm{O}$ and $\mathrm{V}$, respectively, which means their comparison is between ERPs to nouns and verbs. They continue to describe the effect thus obtained as an "anterior negativity", comparing it to effects found in previous studies, which, however, usually refer to it as a Left Anterior Negativity (LAN). In fact, the negativity is neither particularly anterior, nor left lateralized. It is timed between 300 and $500 \mathrm{~ms}$ post-critical-stimulus and its distribution is bilateral, from anterior to posterior electrodes (e.g., clearly present on electrodes $\mathrm{Cp} 1, \mathrm{Cp} 2$ and $\mathrm{Pz}$ ). The topography and latency of the ERP difference between the $\mathrm{SOV}_{\mathrm{f}}$ and $\mathrm{SV}_{\mathrm{f}} \mathrm{O}$ sentences resemble a classical N400 (Kutas and Hillyard 1984), as much as a LAN, be it rather anterior, which makes it even more likely that the obtained differences (partly) have a lexical-semantic origin, as the direct comparison is between nouns and verbs in this experiment.

Weyerts et al. (2002) present an additional experiment to investigate the difference in ERPs to their verb and noun stimuli in a lexical decision task, showing that, if anything, presentation of verbs results in a greater N400 effect. However, it must be noted that these results of noun and verb ERPs outside of sentence context are in direct contrast to other studies, which generally show a greater N400 amplitude for nouns (with an earlier peak), compared to verbs, both in lexical decision or matching tasks (Rösler et al. 2001; Federmeier et al. 2000), as in sentence contexts (Khader et al. 2003, exp. 1). ${ }^{3}$ At the least, such effects may interfere with what Weyerts et al. describe as a syntactic anterior negativity component. All in all, we feel that it is not established beyond doubt that German $\mathrm{SOV}_{\mathrm{f}}$ constructions show a greater negative syntactic ERP component than $\mathrm{SV}_{\mathrm{f}} \mathrm{O}$ constructions.

\footnotetext{
${ }^{3}$ In a study to syntactic violations in Dutch, Hagoort et al. (2003) also report a bilateral anterior negativity, rather than a LAN, in response to phrase structure violations. As in the Weyerts et al. (2002) study, however, their comparisons are crucially between nouns and verbs (in this case with the verbs comprising a syntactic violation). In fact, for purposes of matching between these two word categories, they reduced the cloze probability of the syntactically correct nouns to zero, with the side-effect of increasing the N400 component to these items. It may therefore be possible that in this case as well, 'syntactic' ERPs were tainted by 'lexical/semantic' N400 effects.
} 
Based on their data and analysis, Weyerts et al. (2002) argue that German shows a preference for the V2 word order over the verb-final word order. This preference is so strong that it even survives ungrammatical use of the V2 construction. In terms of a processing model (Gibson 1998), finite verbs want to stay close to subjects, with which they form syntactic 'agreement' relations, and when the parser encounters a subject, or thematic actor, it expects a verb to raise its head immediately. Despite the methodological remarks we place here, we agree to a large extent with the processing account of a subject-verb order preference in sentence parsing, as defended by Weyerts et al. (2002). For example, the absence of (E)LAN effects in our own data may be related to this. One possibility is that the verb following a subject does not immediately raise the alarm, precisely because it is a very frequent cooccurence, which may even conform to pragmatic preferences of subject-verb adjacency. However, problems come to light as soon as the syntactic information needs to be integrated into the sentence structure, revealing the violation of conditions for V2.

Therefore, a semantic/pragmatic processing preference for V2 (SVO) in Dutch cannot be the whole story. Both in comprehension and in production, sentence (de)construction relies not only on semantic or pragmatic parameters, but also on syntactic parameters. It is these syntactic parameters that we argue are at the core of production and (subtle) comprehension problems in speakers with agrammatic aphasia, who have no discernible problem with semantics or pragmatics.

In a syntactic account of Dutch verb placement, which is very much like German verb placement, the V2 construction is a derived form, compared to the verb-final construction found in embedded clauses. This syntactic analysis of extra processing effort for V2 constructions runs counter to frequency data (cf. Den Ouden et al. 2008; Bastiaanse et al. 2009) and it is perfectly possible that it also runs counter to semantic or pragmatic preferences of processing. Competition of language constraints of different levels and types, however, certainly does not mean these are incompatible, so it may well be that syntactic, semantic and pragmatic constraints on structure preference compete in sentence processing and production, on the road to optimal wellformedness.

Finally, we note that our verb stimuli are followed by a sustained, or slow negative wave over anterior electrodes. Although this was not the object of our limited investigation, and would require more elaborate and targeted analysis, we speculate that this frontal negative wave may be reflective of working memory processing (Ruchkin et al. 1990; Honda et al. 1996; Fiebach et al. 2001). Such processing load may increase in anticipation of the object noun phrase that will necessarily follow the transitive verb and which will have to be integrated into its meaning representation, to satisfy its argument structure subcategorization requirements. Alternatively, it may increase with the activation maintenance of the verb throughout its clause. Cross-modal lexical priming experiments by De Goede et al. (2005) suggest that Dutch verbs in V2 position remain activated throughout their entire clause, as opposed to nouns, which are known to be deactivated after presentation during online parsing and are only reactivated in case of filler-gap dependencies, at the position of their syntactic trace (Swinney et al. 1988; Love and Swinney 1996).

\section{Conclusion}

In electrophysiological measurements of auditory sentence processing, violations of Dutch V2, in which verbs are ungrammatically placed in second position in embedded clauses, are followed by a syntactic P600 component. Therefore, there is no indication that an $\mathrm{SV}_{\mathrm{f}} \mathrm{O}$ order preference in sentence processing overrides syntactic constraints on sentence structure 
in Dutch, as suggested earlier by Weyerts et al. (2002) for German. V2 is a construction that only occurs when its syntactic structural conditions are met (cf Zwart 2001), in which case it is possibly associated with increased processing cost in production, if not in comprehension, relative to constructions in which finite verbs remain in their base sentence(-final) position (Den Ouden et al. 2008).

In a follow-up study, we plan to investigate the electrophysiological response to V2 violations in agrammatic aphasic speakers, who are known to have greater problems with V2 production than with V2 comprehension. The question then is whether the aphasic speakers use an intact form of syntactic processing, as in unimpaired speakers, or whether their ERPs are fundamentally different, suggesting they may use an extrasyntactic processing method in comprehension.

Acknowledgements This research was supported by the Netherlands Organization for Scientific Research (NWO; grant \# VPR-00-02 to RB). Furthermore, we wish to thank Walter Schirm and Nynke van den Bergh for their help with preparing the stimuli and Peter Albronda for technical assistance.

Open Access This article is distributed under the terms of the Creative Commons Attribution Noncommercial License which permits any noncommercial use, distribution, and reproduction in any medium, provided the original author(s) and source are credited.

\section{Appendix}

\section{Critial Stimuli}

\section{Correct Verb Second sentences}

1. De professor spreekt en de onderzoeker toetst zijn hypothese The professor speaks and the researcher tests his hypothesis

2. De abt knikt en de monnik dankt zijn Schepper The Abt nods and the monk thanks his Creator

3. De kok kookt en het hulpje hakt groente The cook cooks and the assistant chops vegetables

4. De reiziger ontbijt en de herbergier perst zijn sinaasappel The traveler eats and the landlord squeezes his orange

5. De huishoudster kookt en de tiener leert zijn tentamen The housekeeper cooks and the teenager studies for his exam

6. Het proefwerk begint maar de spijbelaar bouwt een hut The test begins, but the truant builds a hut

7. Het bezoek blijft maar de moeder voedt haar baby The guests stay but the mother feeds her baby

8. De sergeant moppert maar de soldaat dient zijn land The sergeant complains but the soldier serves his country

9. De huurprijs stijgt maar het tweetal deelt een woning The rent increases but the couple shares a home

10. De regisseur stopt maar de stuntman durft een boel The director stops but the stuntman dares a lot

11. De mensen klappen want de atleet werpt zijn speer The people applaud because the athlete throws his javelin

12. De koopman aarzelt want de klant biedt een tientje The merchant hesitates because the customer offers a tenner 
13. Het kind schrikt want de hond bijt het katje The child starts because the dog bites the kitten

14. De uitgever juicht want de auteur boeit het publiek The publisher cheers because the author captivates the audience

15. De gast staat en een serveerster dekt het tafeltje The guest stands and the waitress sets the table

16. De regering huivert want het volk kiest een vrouw The government shudders because the people elect a woman

17. De oppas belt want de kleuter mist zijn vader The babysitter calls because the child misses his father

18. De docent zucht want de puber haat zijn school The teacher sighs because the teenager hates his school

19. De winkeliers protesteren maar de gemeente heft belasting The shopkeepers protest but the council imposes taxes

20. De menigte joelt want de astronaut zoent zijn vrouw The crowd roars because the astronaut kisses his wife

21. De hardloper rent en de turnster rekt haar spieren The runner runs and the gymnast stretches her muscles

22. De reu rust en de puppy likt zijn baasje The dog rests and the puppy licks his master

23. De arbeiders slapen maar de bakker bakt het brood The workers sleep but the baker bakes the bread

24. De boswachter schoffelt en een wandelaar plukt bosbessen The forester weeds and the hiker picks blueberries

25. De kopgroep versnelt maar de wielrenner plakt zijn band The leaders accelerate but the cyclist repairs a puncture

26. De ezel balkt en het paard trapt zijn ruiter The donkey brays and the horse kicks its rider

27. De fotografen komen want de kapper knipt het sterretje The photographers arrive because the hairdresser cuts the starlet

28. De fietser wacht want de voetganger groet zijn collega The cyclist waits because the pedestrian greets his colleague

29. De bootsman dweilt en een matroos hijst het grootzeil The boatswain mops and a sailor hoists the mainsail

30. De boer ontspant want een os trekt zijn kar The farmer relaxes because an ox pulls his cart

31. De brandweer arriveert want de inwoner ruikt het aardgas The firemen arrive because the resident smells the gas

32. De boef ontkomt maar de toerist meldt het delict The villain escapes but the tourist reports the crime

33. De kerkdienst eindigt en de koster luidt de klok The service ends and the sexton rings the bell

34. De prijzen stijgen en de zakenman telt zijn geld The prices increase and the businessman counts his money

35. De valk verhongert want de buizerd grijpt zijn prooi The falcon starves because the buzzard catches its prey

36. Het trapje valt en de weduwe breekt haar been The stepladder topples and the widow breaks her leg 
37. Het kamermeisje grinnikt want de piccolo draagt het koffertje The chambermaid chuckles because the bell-boy carries the suitcase

38. De uitverkoop start en het nichtje roept haar vriend

The sale starts and the cousin calls her friend

39. De tent lekt en een wesp prikt de kampeerder The tent leaks and a wasp stings the camper

40. De kruidenier bukt en de belhamel pikt het snoepje The grocer stoops and the rascal steals the candy

\section{Verb Second Violations}

41. *De beleggers verdwijnen omdat de secretaresse leidt het bedrijf The investors vanish because the secretary leads the company

42. *De bewoner schreeuwt omdat de inbreker pakt zijn mes The resident yells because the burglar grabs his knife

43. *De bezoekers sidderen terwijl de dompteur voert zijn leeuw The visitors shudder while the animal trainer feeds his lion

44. *De leraar zeurt omdat de scholier leest een stripboek The teacher nags because the student reads a comic book

45. *De fans gillen omdat de zangeres toont haar gezicht The fans scream because the singer shows her face

46. *De gedupeerde bedaart omdat de advocaat eist smartegeld The dupe calms down because the lawyer demands damages

47. *De goochelaar baalt omdat de assistente raadt het antwoord The magician is cheesed off because the assistant guesses the answer

48. *De herten vluchten terwijl de jager laadt zijn geweer The deer flee while the hunter loads his gun

49. *De interviewer wacht terwijl de kampioen vult zijn glas The interviewer waits while the champion fills his glass

50. *Het jongetje lacht omdat een tante duwt zijn schommel The boy laughs because the aunt pushes his swing

51. *De juffrouw kalmeert omdat de held redt haar peuter The lady calms down because the hero saves her toddler

52. *De klas giechelt omdat de meester wekt zijn leerling The class giggles because the teacher wakes his pupil

53. *De kleindochter niest omdat de opa veegt zijn stoepje The granddaugher sneezes because grandpa sweeps the pavement

54. *De koopvaarder zwicht omdat de piraat richt zijn kanon The merchantman yields because the pirate aims his cannon

55. *De oma fluistert terwijl het meisje lokt het konijntje The grandma whispers while the girl lures the rabbit

56. *De ouders treuren omdat de student huurt een kamer The parents mourn because the student rents an appartment

57. *De overvaller verstijft omdat de agent lost een schot The robber freezes because the policeman fires a shot

58. *De pers jubelt omdat de filmster viert haar verjaardag The press cheers because the movie star celebrates her birthday

59. *De politie arriveert omdat de oplichter leent een auto The police arrive because the swindler borrows a car 
60. *De schrijver glundert omdat de dame koopt het boek The writer beams because the lady buys a book

61. *De stagair kijkt terwijl de weerman meet de temperatuur The trainee watches while the weatherman measures the temperature

62. *De supporters zingen hoewel de voetballer raakt het stadiondak The fans sing although the soccer player hits the stadium roof

63. *De vloer kraakt terwijl de verhuizer tilt het orgel The floor creaks while the mover lifts the harmonium

64. *Het kasteel vergaat hoewel de ridder doodt een draak The castle perishes although the knight kills a dragon

65. *Het lawaai verstomt omdat de jongen kust zijn vriendin The noise dies down because the boy kisses his girlfriend

66. *Het parlement weigert hoewel de politicus reikt zijn hand Parliament refuses although the politician extends his hand

67. *Het schilderij mislukt tenzij de schilder mengt zijn verf The painting fails unless the artist mixes his paints

68. *Het team verliest hoewel de sportman gooit zijn speer The team lose although the sportsman throws his javelin

69. *De machinist toetert omdat de automobilist kruist een spoorweg The engineer hoots because the motorist crosses a railway

70. *De brouwer trakteert terwijl de jubilaris proeft het bier The brewer treats while the birthday boy tastes the beer

71. *De scheidsrechter fluit omdat de basketballer plaagt zijn tegenstander The referee whistles because the basketball player chaffs his opponent

72. *De klanten vertrekken tenzij de handelaar prijst zijn koopwaar The customers leave unless the dealer marks/praises his merchandise

73. *De subsidie stopt hoewel de bioloog kweekt zijn planten The subsidy stops although the biologist cultivates his plants

74. *De stadswacht rust terwijl de zwerver pleegt het misdrijf The town guard rests while the vagrant commits a crime

75. *De onderwijzeres schreeuwt omdat het ventje knijpt zijn zusje The teacher screams because the boy pinches his sister

76. *De journalist ontspant terwijl de ontwerper kleedt het fotomodel The reporter relaxes while the designer dresses the model

77. *De storm nadert terwijl de tuinbouwer raapt zijn appels The storm approaches while the gardener picks his appels

78. *De omstanders applaudisseren omdat de schutter treft het doelwit The bystanders applaud because the marksman hits the target

79. *De toneelmeester gluurt terwijl de danseres past haar jurk The stage manager peeks while the dancer tries on her dress

80. *De redacteur piekert hoewel de drukker drukt het tijdschrift The editor worries although the printer prints the magazine

\section{References}

American Electroencephalographic Society. (1994). Guidelines for standard electrode position nomenclature. Journal of Clinical Neurophysiology, 11, 111-113. 
Baayen, R.H., Piepenbrock, R., \& Gulikers, L. (1995). The CELEX Lexical Database (Release 2) [CD-ROM]. Philadelphia, PA: Linguistic Data Consortium, University of Pennsylvania [Distributor].

Bastiaanse, R., Bol, G., Van Mol, S., \& Zuckerman, S. (2002). Verb Movement and finiteness in language impairment and language development. In E. Fava (Ed.), Clinical Linguistics: Theory and Applications in Speech Pathology and Therapy (Current Issues in Linguistic Theory 227). Philadelphia: John Benjamins, pp. 119-130.

Bastiaanse, R., Bouma, G., \& Post, W. (2009). Linguistic complexity and frequency in agrammatic speech production. Brain and Language, 109, 18-28. doi:10.1016/j.bandl.2008.12.2004.

Coulson, S., King, J.W., \& Kutas, M. (1998). Expect the unexpected: event-related brain responses of morphosyntactic violations. Language and Cognitive Processes, 13, 21-58. doi:10.1080/016909698386410.

De Goede, D., Wester, F., Den Ouden, D.B., Bastiaanse, R., Shapiro, L.P., \& Swinney, D.A. (2005) The time course of verb processing in Dutch sentences. In K. Forbus, D. Gentner, \& T. Regier (Eds.), Proceedings of the twenty-sixth annual conference of the Cognitive Science Society, Chicago, Illinois, 4-7 August 2005, pp. 279-284.

Den Besten, H. (1977) On the interaction of root transformations and lexical deletive rules. Ms, MIT/Universiteit van Amsterdam. Published in Studies in West-Germanic Syntax, 1989, dissertation, University of Amsterdam.

Den Ouden, D.B., Hoogduin, H., Stowe, L.A., \& Bastiaanse, R. (2008). Neural correlates of Dutch Verb Second in speech production. Brain and Language, 104, 122-131. doi:10.1016/j.band1.2007.05.001.

Federmeier, K.D., Segal, J.G., Lombrozo, T., \& Kutas, M. (2000). Brain responses to nouns, verbs and classambiguous words in context. Brain, 123, 2552-2566. doi:10.1093/brain/123.12.2552.

Ferree, T.C., Luu, P., Russell, G.S., \& Tucker, D.M. (2001). Scalp electrode impedance, infection risk, and EEG data quality. Clinical Neurophysiology, 112, 536-544. doi:10.1016/S1388-2457(00)00533-2.

Fiebach, C.J., Schlesewsky, M., \& Friederici, A.D. (2001). Syntactic working memory and the establishment of filler-gap dependencies: Insights from ERPs and fMRI. Journal of Psycholinguistic Research, 30(3), 321-338. doi:10.1023/A:1010447102554.

Friederici, A.D. (1995). The time course of syntactic activation during language processing: a model based on neuropsychological and neurophysiological data. Brain and Language, 50, 259-281. doi:10.1006/brln. 1995.1048.

Friederici, A.D. (2002). Towards a neural basis of auditory sentence processing. Trends in Cognitive Sciences, 6, 78-84. doi:10.1016/S1364-6613(00)01839-8.

Friederici, A.D., \& Frisch, S. (2000). Verb argument structure processing: The role of verb-specific and argument-specific information. Journal of Memory and Language, 43, 476-507. doi:10.1006/jmla.2000.2709.

Friederici, A.D., Pfeifer, E., \& Hahne, A. (1993). Event-related brain potentials during natural speech processing: Effects of semantic, morphological and syntactic violations. Brain Research. Cognitive Brain Research, 1, 183-192. doi:10.1016/0926-6410(93)90026-2.

Friederici, A.D., Von Cramon, D.Y., \& Kotz, S.A. (1999). Language related brain potentials in patients with cortical and subcortical left hemisphere lesions. Brain, 122, 1033-1047. doi:10.1093/brain/122.6.1033.

Frisch, S., Hahne, A., \& Friederici, A.D. (2004). Word category and verb-argument structure information in the dynamics of parsing. Cognition, 91, 191-219. doi:10.1016/j.cognition.2003.09.009.

Gibson, E. (1998). Linguistic complexity: Locality of syntactic dependencies. Cognition, 68, 1-76. doi:10. 1016/S0010-0277(98)00034-1.

Gratton, G., Coles, M.G.H., \& Donchin, E. (1983). A new method for the off-line removal of ocular artifact. Electroencephalography and Clinical Neurophysiology, 55, 468-484. doi:10.1016/ 0013-4694(83)90135-9.

Hagoort, P. (2005). On Broca, brain, and binding: a new framework. Trends in Cognitive Sciences, 9, 416-423.

Hagoort, P., Wassenaar, M., \& Brown, C.M. (2003). Syntax-related ERP-effects in Dutch. Cognitive Brain Research, 16, 38-50. doi:10.1016/S0926-6410(02)00208-2.

Honda, M., Barrett, G., Yoshimura, N., Ikeda, A., Nagamine, T., \& Shibasaki, H. (1996). Event-related potentials during paired associate memory paradigm. Electroencephalography and Clinical Neurophysiology, 98, 206-212. doi:10.1016/0013-4694(95)00239-1.

Kaan, E., Harris, A., Gibson, E., \& Holcomb, P. (2000). The P600 as an index of syntactic integration difficulty. Language and Cognitive Processes, 15, 159-201. doi:10.1080/016909600386084.

Khader, P., Scherag, A., Streb, J., \& Rösler, F. (2003). Differences between noun and verb processing in a minimal phrase context: A semantic priming study using event-related brain potentials. Brain Research. Cognitive Brain Research, 17, 293-313. doi:10.1016/S0926-6410(03)00130-7.

Kutas, M., \& Hillyard, S.A. (1984). Brain potentials during reading reflect word expectancy and semantic association. Nature, 307, 161-163. doi:10.1038/307161a0. 
Love, T., \& Swinney, D. (1996). Coreference processing and levels of analysis in object-relative constructions; demonstration of antecedent reactivation with the crossmodal priming paradigm. Journal of Psycholinguistic Research, 25, 5-24. doi:10.1007/BF01708418.

Neville, H.J., Nicol, J., Barss, A., Forster, K.I., \& Garrett, M.F. (1991). Syntactically based sentence processing classes: Evidence from event-related brain potentials. Journal of Cognitive Neuroscience, 3, 151-165. doi:10.1162/jocn.1991.3.2.151.

Osterhout, L., \& Holcomb, P.J. (1992). Event-related potentials and syntactic anomaly. Journal of Memory and Language, 31, 785-804. doi:10.1016/0749-596X(92)90039-Z.

Osterhout, L., \& Holcomb, P. (1993). Event-related potentials and syntactic anomaly: Evidence of anomaly detection during the perception of continuous speech. Language and Cognitive Processes, 8, 413-438. doi:10.1080/01690969308407584.

Osterhout, L., Holcomb, P.J., \& Swinney, D.A. (1994). Brain potentials elicited by garden-path sentences: Evidence of the application of verb information during parsing. Journal of Experimental Psychology. Learning, Memory, and Cognition, 20, 786-803. doi:10.1037/0278-7393.20.4.786.

Rispens, J. (2004). Syntactic and Phonological Processing in Developmental Dyslexia. Doctoral dissertation, University of Groningen, GRODIL 48.

Rösler, F., Streb, J., \& Haan, H. (2001). Event-related brain potentials evoked by verbs and nouns in a primed lexical decision task. Psychophysiology, 38, 694-703.

Ruchkin, D.S., Johnson, R., Jr, Canoune, H., \& Ritter, W. (1990). Short-term memory storage and retention: An event-related brain potential study. Electroencephalography and Clinical Neurophysiology, 76, 419-439. doi:10.1016/0013-4694(90)90096-3.

Schneider, W., Eschman, A., \& Zuccolotto, A. (2002). E-Prime Reference Guide. Pittsburgh: Psychology Software Tools Inc.

Shapiro, L.P. (2003). Argument structure: Representation and Processing. In: R. Kent (Ed.), The MIT Encyclopedia of Communication Disorders. Cambridge, MA: MIT Press, pp. 269-271.

Shapiro, L.P., Brookings, B., Gordon, B., \& Nagel, N. (1991). Verb effects during sentence processing. Journal of Experimental Psychology. Learning, Memory, and Cognition, 17(5), 983-996. doi:10.1037/0278-7393. 17.5.983.

Swinney, D.A., Ford, M., Bresnan, J., \& Frauenfelder, U.L. (1988). On the temporal course of gap-filling and antecedent assignment during sentence processing. In: B. Grosz, R. Kaplan, M. Macken, \& I. Sag (Eds.), Language Structure and Processing. Stanford, CA: CSLI.

Ullman, M.T. (2004). Contributions of memory circuits to language: the declarative/procedural model. Cognition, 92, 231-270. doi:10.1016/j.cognition.2003.10.008.

Van den Brink, D. (2004) Contextual Influences on Spoken-Word Processing. Doctoral dissertation. University of Nijmegen. MPI Series in Psycholinguistics.

Weyerts, H., Penke, M., Münte, T., Heinze, H.-J., \& Clahsen, H. (2002). Word order in sentence processing: An experimental study of verb placement in German. Journal of Psycholinguistic Research, 31, 3, 211-268; also in Essex Research Reports in Linguistics, 31, 1-44.

Zwart, C.J.W. (2001). Syntactic and phonological verb movement. Syntax, 4(1), 34-62. doi:10.1111/ 1467-9612.00036.

Zwart, C.J.W. (2003) Agreement and remnant movement in the domain of West-Germanic verb movement. In: J. Koster \& H. van Riemsdijk (Eds.), Germania et Alia: A Linguistic Webschrift for Hans den Besten. Groningen: University of Groningen. 